\title{
A MORADA DA MORAL NO PENSAMENTO DE FREI BERNARDINO LEERS: A PESSOA*
}

Ethos in the thinking of Father Bernardino Leers: the person

\author{
Amauri Carlos Ferreira** \\ Frei Leonardo Lucas Pereira***
}

\begin{abstract}
A consciência moral não é monopólio dos moralista ${ }^{1}$.
\end{abstract}

RESUMO: Este artigo discute a importância do pensamento de Frei Bernardino Leers para a virada pragmática da teologia moral. Com este objetivo, revisitaram-se algumas das suas obras numa tentativa de entender de que maneira seu pensamento influenciou o modo de fazer teologia moral. Essa reflexão evidencia dilemas e conflitos no que se refere à prática dos moralistas tradicionais em relação ao mundo vivido. Nesse processo de investigação, encontram-se alguns fundamentos da ética aplicada. De forma especular, Frei Bernardino Leers propõe aos moralistas católicos um olhar para a pessoa em sua singularidade, chamando-os para uma escuta de cuidado e respeito ao ser humano. Tal atitude de ser e viver reconstrói a morada do ethos moral.

Palavras-Chave: Teologia Moral, Pessoa, Dilemas, Conflitos, Ética aplicada.

AвSTRACT: In this paper we discuss the importance of Father Bernardino Leers' thoughts for the pragmatic reorientation of moral theology. We try to understand his trend of thought by revisiting his works, and identify how they influence the

\footnotetext{
* In memoriam a Frei Bernardino. Uma versão preliminar deste artigo foi entregue a Frei Bernardino, em 2009, que o considerou importante. Artigo submetido a avaliação em 18/ 03/2012 e aprovado em 03/04/2012.

** Pontifícia Universidade Católica de Minas Gerais, Belo Horizonte.

*** Pontifícia Universidade Católica de Minas Gerais; Instituto Santo Tomás de Aquino, Belo Horizonte.

${ }^{1}$ B. LEERS, Em Plena Liberdade, Belo Horizonte: Lutador, 2010a, p. 82.
} 
making of moral theology. This analysis brings to light dilemmas, and conflicts to the traditional moral practice experienced in the world. During the investigation, we identify the principles of applied ethics in Father Bernardino's thoughts. In a specular manner, Father Bernardino summons Catholic moralists to focus on a person's singularity, listening carefully and respecting the human being. Such an attitude of living and being underlies the construction of an ethos.

Keywords: Moral Theology, Person, Dilemmas, Conflicts, Applied ethics.

\title{
Introdução
}

\begin{abstract}
condição humana é o lugar privilegiado do ethos ${ }^{2}$. A busca pela construção e reconstrução de uma moradia que nunca está pronta, perfeita, é atitude ética dos seres humanos. Quanto mais se aventura no estudo da moralidade mais se percebe a complexidade do homem em suas buscas, em seus conflitos e dilemas. É um ser que tenta desentranhar do reino da quase necessidade a liberdade de ser e de estar com os outros no mundo.
\end{abstract}

No século $X X$, a questão central em torno de reflexões a respeito da vida e da relação com o outro aponta um caminho para melhor compreensão sobre a moralidade. La Taille ${ }^{3}$ afirma que em 1902, Lévy-Bruhl publicou La Morale et La Science des Moeurs, destacando a importância da moral e chamando a atenção para que ela se tornasse objeto da ciência. No mesmo ano Durkheim ministrava cursos sobre educação moral. Nos anos 20 Freud publicava seu texto sobre o Id e o Ego. Piaget publica, no início dos anos 30, O julgamento Moral da Criança.

Durante a primeira metade do século XX, as reflexões em torno do comportamento moral dos indivíduos estavam circunscritas à relação lógica de julgamentos morais e também a outras formas, a contribuição da filosofia moral anglo-saxônica no campo da metaética ${ }^{4}$, que não pretendia e nem

\footnotetext{
${ }^{2}$ Ethos - termo grego que significa casa, morada, lugar. No dizer de Lima Vaz (Escritos de Filosofia II: Loyola, 1988, p. 16). "Ethos como lei é, verdadeiramente, a casa, a morada da liberdade".

${ }^{3}$ Cf. Y. de LA TAILLE, Vergonha a Ferida Moral, Petrópolis: Vozes, 2002, p. 15-16.

${ }^{4}$ Durante a primeira metade do século XX, a filosofia moral anglo-saxônica preocupouse com discussões em torno da meta-ética, que vem a ser, o estudo do significado dos termos morais da relação lógica entre os julgamentos morais e outras formas de julgamentos. Uma preocupação com os enunciados morais que tangenciavam predicados neutros de moralidade, tais como bem, bom, justo e dever, entre outros. As questões de conteúdo moral eram discutidas a partir de perspectivas disciplinares que defendiam posições ideológicas, fossem dogmáticas ou relativistas.
} 
pretende determinar o que o ser humano deve fazer. Uma virada reflexiva estava sendo gerada, circunscrita às mudanças sociais que marcaram a sociedade ocidental dos anos 50 do século passado: liberação sexual, direitos sociais e coletivos, direito dos animais, preocupações ambientais, manipulação de técnicas da matéria animada.

A preocupação daqueles autores era procurar fundamentos para a moralidade fora de espaços a ela atribuídos, como nas instituições religiosas ou familiares que estabeleciam o caráter prático e normativo da moral.

Pelo caminho do vivido, Frei Bernardino Leers insere-se nesse contexto discutindo temas que se tornaram centrais a partir do período pós Segunda Guerra Mundial. Sua reflexão aponta, nessa práxis, a pessoa como morada da moral, substrato primeiro de reflexões morais que irão se seguir a posteriori.

O eixo reflexivo da morada do ser humano volta-se para questões de ordem prática e de sua aplicação. Este passa a ser o eixo da ética aplicada ${ }^{5}$. Termo que gera desconforto para a teoria geral da ética, uma vez que a mesma está voltada diretamente à filosofia prática.

Sem falar em ética aplicada, Frei Bernardino Leers demonstra preocupação desde o início de sua vida acadêmica com conflitos e dilemas em torno da pessoa com especificidade no campo da teologia moral. O pensamento e a ação desse autor, desde sua origem, está centrado na pessoa, o que o levou a refletir sobre a subjetividade na práxis da moral teológica. Tal preocupação, em seu magistério, evidenciou conflitos do ser pessoa em relação ao mundo vivido, o que proporcionou uma virada pragmática no fazer teológico.

Para compreender seu pensamento inovador, no campo da moral, revisitamos algumas das suas obras numa tentativa de entender essa virada pragmática e de que maneira influenciou o modo de se fazer teologia moral e de que forma se aproxima da ética aplicada. Assim, esse artigo está circunscrito aos seguintes percursos: a morada da moral teológica em seus dilemas e conflitos, desafios da teologia moral em tempos de mudanças e a morada da ética aplicada e desafios ao confessor.

\footnotetext{
${ }^{5}$ A expressão ética aplicada surgiu nos Estados Unidos nos anos 60 do século passado. Nos anos 70 as questões de ordem ética sedimentaram-se em áreas do conhecimento que tangenciavam o campo interdisciplinar como bioética, ética ambiental, ética profissional, ética e educação, dentre outras que caracterizam um ramo específico da ética geral.
} 


\section{1 - A morada da Teologia Moral é a pessoa: dilemas e conflitos}

Aqui eu descobri ainda um clero que era realmente de mando ${ }^{6}$

A chegada de Bernardino Leers no Brasil dos anos 50 do século XX, no interior de Minas Gerais, vindo de um doutorado em Teologia Moral em Roma, abre possibilidades para ampliar sua percepção sobre a moral oficial católica no contato com a cultura local. Em sua acuidade de saber escutar, apreende o movimento dinâmico do ethos mineiro e o amplia na compreensão de dilemas e conflitos vividos pelo ser pessoa. É assim que sua consciência, voltada para a humanidade, foi capaz de polemizar assuntos como a limitação de filhos, uso da pílula, aborto, divórcio, sexualidade humana, homossexualidade, entre outros. Temas esses que estavam sendo discutidos, problematizados, vividos e, no entanto, moralizados e inseridos na tradição teológica.

O apego rígido à tradição moral pode levar a um distanciamento do mundo vivido. Entender o momento atual é permitir olhar para além da teoria e do pensamento dogmático. Isso requer a compreensão dos valores de cada geração que chega ao mundo, seus conflitos e dilemas. Essa aplicabilidade da ética, no que alude ao dever e ao conflito, sempre existiu; a questão atual é que as perguntas voltam-se para o sujeito em situações dilemáticas, no que se refere à moral em torno de escolhas e decisões.

O dilema moral, bem como o conflito, acham-se circunscritos ao campo do dever. É a pergunta de ordem da moral: "o que devo fazer"? A resposta a essa pergunta, na sociedade contemporânea, situa-se no mundo do sujeito em suas escolhas temerárias, em que escolher é sempre sinônimo de perda. São situações nas quais as ações que emergem levam o sujeito à realização de uma delas. Tal perspectiva, ao se voltar para o sujeito em sua autonomia, leva-o a assumir responsabilidades circunscritas ao plano da ação ética. Daí que as situações dilemáticas conduzem o sujeito a repensar sua ação no mundo e a reconstruir seu ethos, no campo de situações-limite enfrentadas.

Compreender dilemas, deveres e conflitos na dimensão da moral teológica, e de que maneira eles se interagem na práxis do ethos cristão, e especificamente católico, é entender o modo de refletir de Frei Bernardino em seu fazer teológico, a partir do mundo vivido. Segundo ele,

A moral não é em primeiro lugar teoria, conjunto de palavras e frases, eventualmente, normas e proibições; subsiste e se realiza na prática do agir,

${ }^{6}$ B. LEERS, "Frei Bernardino - Um jeito de Viver: Sociedade religião e moral", in L.L. PEREIRA; S.F.P. TOSTA (Org.), Petrópolis: 2000, p. 74. 
interpretar, querer, decidir, executar das pessoas concretas que, como as pessoas mesmas, estão submetidas ao tempo e espaço mutáveis. [...] Um quadro só de valores não corresponde à realidade humana. Ao contrário, na experiência humana os desvalores da realidade fazem perceber os valores como projetos históricos de dignidade humana, de justiça, de amor, de liberdade, fazem sentir em profundidade a humilhação, a injustiça, o ódio e a escravidão ${ }^{7}$.

Compreender valores do tempo vivido conduz a conflitos na área já sedimentada como o certo para uma determinada sociedade e geração. A moral é fruto de valores atribuídos a pessoas concretas que precisam ser compreendidas e percebidas sem conceito prévio, numa perspectiva de crise de valores. Segundo Arendt, "Uma crise só se torna um desastre quando respondemos a ela com juízos pré-formados, isto é, com preconceitos" $^{\prime \prime}$. Uma crise de valores leva-nos a entender qual é a origem dessa mudança valorativa, para perceber a escala de valores da geração que chega ao mundo.

Para Frei Bernardino ${ }^{9}$, ela (moral) é subjetividade, intersubjetividade, realização de sujeitos, um fenômeno humano que participa intimamente das duas dimensões da existência do pensamento e da ação das pessoas: o tempo e o espaço vividos. Entender o momento atual no espaço do vivido é permitir olhar para além da teoria e do pensamento dogmático, a procura incessante do ser humano em viver bem, de acordo com a sua consciência. É a vida comum anterior a qualquer teoria. É esse freqüentar o mundo, que nas palavras de Frei Bernardino está situado o campo da práxis moral. Assim,

[...] Anterior a qualquer teorização, importa a práxis dos agentes morais que agindo, querem realizar o que possuem em potencialidade humana. E a grande multidão de construtores morais na sociedade é o povo simples que nasce, casa-se, cria sua família e morre. A historiografia geralmente se ocupa da elite e dos heróis, mas o material humano que fornece a base e o substrato da peregrinação histórica das nações costuma ser o anonimato popular ${ }^{10}$.

Essa reflexão ética nasce do mundo vivido e, a partir dele, o fazer dos homens em seu tempo e seu espaço constrói uma vida boa e possível. Com essa virada para a pessoa em sua singularidade e intersubjetividade, o pensamento de Frei Bernardino vai aperfeiçoando, em sua convivência, o

\footnotetext{
${ }^{7}$ B. LEERS, "Filosofia, moral, ética família e sociedade no Brasil (1964-1984)", in I. RIBEIRO (Org.), Sociedade Brasileira Contemporânea-Família e Valores, São Paulo: Loyola, 1987, p. 129.

${ }^{8}$ H. ARENDT, Entre o passado e o futuro, São Paulo: Perspectiva, 1992, p. 223.

${ }^{9}$ Cf. B. LEERS, "Filosofia, moral, ética família e sociedade no Brasil (1964-1984)", in I. RIBEIRO (Org.), Sociedade Brasileira Contemporânea-Família e Valores, São Paulo: Loyola, 1987, p. 125.

10 Ibid., p. 127.
} 
itinerário flexível do ethos, mostrando que as temáticas morais são do nosso tempo e do nosso lugar. Assim, sua morada moral vai ao encontro de problemas que a ética aplicada passou a refletir tendo em vista dilemas e conflitos vividos pelo ser humano em diálogo com a ordem prescritiva da ética teórica.

Mas de que maneira o pensamento de Frei Bernardino descortina uma nova forma de pensar? Consideramos que se o autor estivesse fora da vida religiosa, seu caminho seria o do triunfo do ser humano em sua busca da felicidade, enfrentando dilemas, conflitos e desafios da vida cotidiana. Como sua unidade de referência valorativa é cristã e católica, tenta refletir sobre o mundo, acompanhar a vida a partir de princípios cristãos e a apontar a rigidez da moral católica em seu apego à "tradição". Com base em sua fé, aprofunda seus estudos bíblicos e cristológicos, examinando com pensamento crítico as deformações históricas da "moral tradicional".

Para Frei Bernardino, é preciso refletir sobre o vivido e estar atento à pessoa do agora. Centrar sua reflexão no mundo vivido, estando na vida eclesiástica, que para ele não é um problema, e sim um desafio. Ele sabe que a mudança a partir da crítica só faz sentido se fizer parte do que se critica e, em seu caso particular, a escolha acertada foi pela sua práxis no meio das pessoas simples. A sabedoria, para ele, nasce da simplicidade. Sua contribuição na origem do ethos popular nos convida a compreender sua atitude transgressora e cuidadosa em relação a morada da ética católica.

No entanto, o apego à tradição moral pode levar a um distanciamento do mundo vivido. Frei Bernardino afirma que, "a palavra 'tradição' é uma palavra perigosa, pois leva facilmente olhar para trás e estudar na biblioteca do passado"11. Essa práxis de estabelecer o que é certo e o que é errado utilizando vozes antigas e moralistas distancia a percepção do ethos em seu movimento de mudança. Não que a tradição seja um problema. $O$ ethos tradicional conserva unidades de referência valorativa que permitem agir no mundo, trazendo de volta experiências que ficaram perdidas no tempo. Segundo Lima Vaz, "a tradição se mostra ordenadora do tempo segundo um processo de reiteração vivente de normas e valores que constitui a cadência própria da história do ethos"12. O comportamento humano é dinâmico e a flexibilidade da morada ética está em abrir possibilidades para se viver bem com o outro. A moral existente como certa é surda em relação à condição dilemática do drama humano.

É no campo dos dilemas, conflitos e deveres que a morada da moral voltase para a pessoa, numa perspectiva do antes e do agora, numa práxis que

${ }^{11}$ B. LEERS, Em Plena Liberdade, Belo Horizonte: Lutador, 2010a, p. 13.

${ }^{12}$ H. LIMA VAZ, Escritos de Filosofia II, São Paulo: Loyola, 1988, p. 19. 
mostra a atitude e a responsabilidade de suas escolhas. Nesse sentido, Frei Bernardino está nesse contexto da possibilidade de voltar a responsabilidade de escolhas do indivíduo para ele mesmo e a partir daí tentar, à medida do possível, provocar reflexões que possam ser consideradas unidades de referências valorativas. Pelos escritos do autor isto parece não ocorrer com teólogos e vários moralistas, que parecem centrados na práxis das pessoas, mas estão apegados ao passado sem vislumbrar o futuro.

Para Frei Bernardino, é o momento de refletir sobre a ação do moralista em seu apego ao passado. No caso do teólogo é fundamental o olhar para frente pois "a teologia moral não é um olhar para trás, é olhar para o futuro"13. Daí ocorre sua crítica aos teólogos moralistas apegados só ao ethos legal, distanciados do mundo da vida. Segundo Frei Bernardino Leers ${ }^{14}$, tradicionalmente, a teologia moral é considerada uma ciência prática que intenciona refletir sobre o agir das pessoas e sociedades, e orientálas em sua caminhada dentro da perspectiva da fé cristã. Sua finalidade ficaria frustrada se seu acervo e conhecimentos, diretivas e normas, se limitasse ao silêncio das bibliotecas esquecidas.

Na Teologia moral ocidental, a atenção, segundo Frei Bernardino ${ }^{15}$, circulava em redor do ato humano ou ato do homem e não da pessoa humana em seu agir. É a práxis do puramente humano que atravessa as reflexões morais de Frei Bernardino, trazendo de volta o conceito de pessoa numa ação voltada para a relação com o outro. Relação que funda a ética e instaura a necessidade de convivência mútua entre seres pertencentes à mesma espécie. É no caráter de igualdade da espécie humana que se abre a possibilidade de um diálogo em que o respeito ao outro se instaura numa atitude de compaixão e de sabedoria. Nos textos de Frei Bernardino Leers, sobre ele e sobre as pessoas que com ele convivem ou com ele conviveram, há o interesse de se compreender o que vem a ser o teólogo moralista.

O que é um moralista numa perspectiva religiosa? O que é fazer teologia moral no território de conflitos e dilemas? Essas indagações atravessam o dever ser do comportamento humano. Entender esse comportamento é se confrontar com a tradição e os ares do novo na práxis religiosa, que tenta compreender o agora e seguir em busca da felicidade. Mas é possível ser feliz com a formação de um imaginário de culpa construído no pecado? Esse é o maior desafio de Frei Bernardino Leers, ao se deparar com o sopro da mudança na rocha da tradição.

O modo como a religião cristã enuncia, às vezes, sua unidade de valor, o medo torna-se uma única mão sem contra-mão, o que nos faz lembrar de

${ }^{13}$ B. LEERS, Em Plena Liberdade, Belo Horizonte: Lutador, 2010a, p. 13.

${ }^{14}$ B. LEERS, "Ensinar Teologia Moral", in M.F. DOS ANJOS (Org.), Articulação da Teologia na América Latina, São Paulo: Santuário, 1986, p. 120.

${ }_{15}$ B. LEERS, Em Plena Liberdade, Belo Horizonte: Lutador, 2010a, p. 62. 
Walter Benjamim ${ }^{16}$ em sua Rua de Mão Única na qual: Toda rua de mão única é também uma contra-mão. Qual é a contra mão da história no que se refere à moral? É sem dúvida nenhuma a tirania do medo, a obediência cega, a impossibilidade de agir de acordo com o espírito do tempo. É no contexto de mudanças que a crise surge, no sentido de trazer a possibilidade de transformar a sociedade em relação à tradição. Segundo Leers,

A moral que entrou em crise é uma forma histórica da moral humana que se formou no ocidente e se irradiou sobre os povos dos outros continentes pelo processo de colonização em grau variado de penetração. A crise com seus conflitos é um fenômeno da atualidade e do contexto dinâmico sóciocultural de hoje. Neste contexto limitado é que nasceram as dúvidas a respeito do sistema herdado dos antepassados, cresceram as críticas e começaram as mudanças do comportamento moral, talvez por agora de pouca estabilidade, mas de qualquer maneira sinais de surgimento dum novo ethos ou do desenvolvimento pluralista e várias formas de vida ${ }^{17}$.

A moral tradicional quer se manter na condição de estabelecer o que deve ser para todo o ser humano. Os novos valores precisam insurgir contra o que já está estabelecido, para daí se construir um novo ethos. Mas como formar um novo ethos quando a práxis moral religiosa está sob o signo do poder violento que dilacera e impede o novo de surgir? Frei Bernardino, com sutileza e ironia, desbanca o poder da tradição ao apontar que a teologia moral, ao caminhar para o futuro, precisa aprender a arte de transgredir, que é efetivamente ética, pois obedece à consciência da pessoa. Consciência que é construída no viver bem. No entanto, a aprendizagem de valores religiosos imposta ao ser humano, a partir da pedagogia do medo, impede que o novo tome seu lugar na dinâmica da vida. $\mathrm{O}$ exemplo dado por Frei Bernardino Leers, no que se refere ao grupo social, é do segmento religioso da Igreja Católica, como sendo "um conjunto social estruturado daqueles que se confessam oficialmente a ela, sem tomar em consideração se participam de suas práticas públicas ou observam suas leis"18. Tal perspectiva aponta a inflexibilidade da religião em relação às culturas e em relação ao ensino da moral cristã, gerando um conflito dentro do legalismo moral do éthos religioso. Uma vez que "da parte dos cristãos há a fácil invocação do nome de Deus para encobrir a imposição autoritária de normas éticas ${ }^{\prime 19}$.

A religião católica traz dentro de sua estrutura eclesiástica a necessidade de formação moral da perspectiva cristã. Nesse sentido, a teologia deve ser prática. Assim a teologia moral "precisa comunicar-se com o público, aju-

\footnotetext{
${ }^{16}$ Cf. W. BENJAMIN, Obras Escolhidas: Rua de Mão Única, São Paulo: Brasiliense, 1993.

${ }^{17}$ B. LEERS, "Moral Tradicional”, Revista logos, Divinópolis, ano II / no 4 , out. 1975, p. 8.

18 Ibid.

19 B. LEERS, Em Plena Liberdade, Belo Horizonte: Lutador, 2010a, p. 114.
} 
dar nas consciências morais, na formação histórica de um mundo mais humano, encarnação evolutiva do Reino de Deus"20.

A teologia moral, como ciência prática, estava circunscrita à casuística. Tratava-se de uma aplicação dos manuais e anotações de pecados. A tradição da teologia moral indicava o que se deve fazer. Uma moral fora de seu contexto. Frei Bernardino, com sua formação em parte na Psicologia e outra em Teologia, em seu depoimento ${ }^{21}$ em 1998 mostra que não ficou animado ao ser convocado a estudar Teologia Moral, mas se animou quando poderia dar nova vida a essa área, aliando Teologia Moral à Psicologia. Foi o que ocorreu em sua vinda para Brasil.

Esse era o projeto que estava em vigor quando Frei Bernardino inicia sua caminhada no campo da moral, pois o que se tinha no período pós-guerra é a marca dos manuais teológicos: Genicot, Noldin, Tanquerey entre outros: uma formação nos moldes da tradição como forma de conservadorismo. A repetição dos manuais sem enxergar a realidade é de certa forma o mecanismo de continuidade da tradição, o que caracterizava o conservadorismo da Igreja Católica, na área da Moral. Para Frei Bernardino,

A Teologia Moral tinha uma preocupação constante com normas. Era simplesmente um bloco de normas, leis, proibições, tabus. Tudo registrado, com sua regulamentação; o que evidentemente interessava muito às autoridades. As autoridades estavam interessadas nessas normas, porque podiam impor a norma e o coitado do súdito que se virasse ${ }^{22}$.

Mas, o que era a Teologia Moral quando ele chega em terras brasileiras e mineiras? A Igreja no Brasil significava o clero. "A igreja era o clero, e ele se ocupava dos sacramentos, se preocupava com a missa, se preocupava com o casamento, com papéis de casamento, burocracia da igreja e assim por diante" ${ }^{23}$. A Igreja não se preocupava e nem se voltava para a pessoa, em seus conflitos e dilemas.

Aproximou-se da convivência com o povo simples. Foi uma experiência marcada pela aventura, obediência e sensibilidade para Frei Bernardino, em sua trajetória num país distante do seu, o que lhe possibilitou voltar-

\footnotetext{
${ }^{20}$ B. LEERS, "Ensinar Teologia Moral", in Articulação da Teologia Moral na América Latina. Teologia Moral na América Latina, M. F. dos ANJOS (Org.), São Paulo: Santuário, 1986, p. 120 .

${ }^{21}$ Depoimento dado aos pesquisadores do grupo de pesquisa Catolicismo e Sociedade da PUC-Minas, transformado em livro em 2000. Cf. L.L. PEREIRA; S.F.P. TOSTA (Org.), Frei Bernardino - Um jeito de Viver: Sociedade religião e moral, Petrópolis: Vozes, 2000. ${ }^{22}$ L. L. PEREIRA; S. F. P. TOSTA (Org.), Frei Bernardino - Um jeito de Viver: Sociedade religião e moral, Petrópolis: Vozes, 2000, p. 58.

${ }^{23}$ Ibid., 80.
} 
se para o outro, e assim entender o ethos popular e a maneira como o clero tratava ou ainda trata o povo. Em sua entrevista ${ }^{24}$ declara:

Eu aprendi ainda a começar certas missas e solenidades com saudações às autoridades eclesiásticas, civis e militares, com a bandeira de Minas, do Brasil e do Vaticano atrás do altar. Um absurdo pra mim. Um absurdo essa mistura de clero, especialmente de alto clero, especialmente do alto clero, com os políticos do lugar... Então descobri um clero de mando. O bispo Dom Cabral quando nos visitava era o príncipe da Igreja. Realmente, respeitem o príncipe. Um absurdo, a gente tinha que primeiro beijar o anel dele, para ele depois dar a comunhão. Ora, achar que Jesus é menos importante do que um homem, que podia ser eu também, isso eu nunca engoli.

Para Frei Bernardino, entender essas atitudes de formação eclesiástica para com o povo é compreender de que maneira os valores são formados e como podem ser modificados. A formação de valores morais vem de instituições como a família, a religião, a escola, entre outras. A religião católica era sinônimo de valores clericais, que impedia a formação de uma práxis a partir do vivido pelo povo.

É interessante notar que o sujeito autônomo se forma a partir de uma norma heterônoma. A norma da moral religiosa tradicional passa a estabelecer o caminho do que é a verdade, sem a possibilidade de transgressão, o que inviabiliza o caráter inovador do ethos. Esse ethos é formado a partir do conflito como possibilidade de mudança e não de conservação irrestrita e absoluta. Os manuais de Teologia Moral apontavam o que, para Frei Bernardino, era um absurdo pois não deixavam o indivíduo tornar-se pessoa. Era a própria oposição ao que Cristo havia deixado. Segundo ele:

Os textos serviram para desanimar qualquer cristão, na ânsia de evitar tantos pecados, o sacrifício da missa era o sacrifício de alto risco mesmo, visto que todas as muitas rubricas tinham o carimbo de pecado mortal, venial, certo, provável. Os mandamentos eram uma selva de entradas proibidas, mais aprendizagem e pecados do que estímulo à vida cristã. $\mathrm{O}$ tratado sobre a vida sexual era uma lista só de pecados mortais de vida solteira e vida casada; graças a Deus era escrito em latim, de modo que não podia escandalizar os pobres leigos ${ }^{25}$.

A teologia moral servia-se dessas anotações de uma vida em pecado, uma teologia autoritária na qual o dever exigia a submissão. O que gerou, na

\footnotetext{
${ }^{24}$ Entrevista concedida ao grupo de pesquisa, Catolicismo e Sociedade da PUC-Minas, transformada em livro. Cf. L.L. PEREIRA; S.F.P. TOSTA (Org.),B. LEERS, Frei Bernardino - Um jeito de Viver: Sociedade religião e moral, Petrópolis: Vozes, 2000.

${ }_{25}$ B. LEERS, "Ensinar Teologia Moral", in M. F. dos ANJOS (Org.), Articulação da Teologia Moral na América Latina. Teologia Moral na América Latina, São Paulo: Santuário, 1986, p. 122.
} 
opinião de Bernardino, um tipo de cristão que vê na vida eclesiástica o óbvio:

Contra o divórcio, contra o aborto, contra a escravidão, contra a corrupção e abusos de poder. Mas os problemas morais que a vida real coloca não se resolvem com proibições globais, nem suas interpretações precisam ser uniformes. A pergunta fundamental é, como a comunidade cristã pode dar maior estabilidade às vidas dos casais, como diminuir o número de aborto por ano, por meios de quais sacrifícios reformar a vida social, econômica e política. Se a moral focaliza o fazer e, fazendo se realiza nas pessoas e pelas pessoas, há mais coisas que entram na realização do que apenas certas instruções dadas pelas autoridades eclesiásticas ${ }^{26}$.

A grande virada no pensamento de Frei Bernardino, em relação à tradição, é pensar a pessoa para além dos manuais e do especialista em pecados. A preocupação é a partir da formação da pessoa no campo de sua autonomia, no sentido de percebê-la não como um ser em pecado, mas um ser de sentimentos; não um ser como objeto, inerte, mudo, surdo, passivo, mas um ser em pura atividade e com novos valores, um ser que duvida, que questiona, enfim um ser humano que merece respeito das autoridades eclesiásticas.

\section{2- A morada da teologia moral em tempos de mudança}

Cada gesto, cada palavra, cada decisão e realização humanas são expressões e produtos de uma pessoa real, de pessoas reais que pisam, vivem e se movimentam na terra comum ${ }^{27}$

Janus, um deus dos começos - a ele é consagrado o mês de janeiro. Representado por duas cabeças, determina o término e prenuncia o começo. Uma cabeça está voltada para o passado, a outra para o futuro. No museu do Vaticano é possível contemplá-lo em sua opulência divina. Considerado um deus das portas, uma vez que a porta abre-se em lados diferentes. Há uma coexistência nas cabeças de Janus, no tempo do agora.

É assim que o pensamento de Frei Bernardino se abre para compreender o passado a partir do presente, propondo de forma sutil sua crítica aos teólogos moralistas, numa linha quase abissal nesse fazer Teologia moral. Se por um lado, os teólogos moralistas não entram num acordo em relação ao seu dever ser, a dupla face de Janus continua apontando para a morada

\footnotetext{
${ }^{26}$ B. LEERS, "Filosofia, moral, ética família e sociedade no Brasil (1964-1984)", in I. RIBEIRO (Org.), Sociedade Brasileira Contemporânea-Família e Valores, São Paulo: Loyola, 1987, p. 132.

${ }^{27}$ B. LEERS, Teologia Moral, Ciências Humanas e Sabedoria Popular: Um Tripé que deu certo, Petrópolis: Vozes, $2010^{\mathrm{b}}$.
} 
do ser enquanto passagem. Nesse sentido, Frei Bernardino chama a atenção para a quase ausência de teólogos morais frente às diversas demandas do mundo contemporâneo, que vão das questões ambientais, passando por questões da sexualidade humana até chegar às reflexões em torno da fé.

É o presente iluminando o passado na expressão de Walter Benjamim, ou nos sonhos acordados de Ernest Bloch. Essa mediação do agora para o passado é encontrada em seu pensamento como uma forma de apontar que a vida moral se realiza construindo um processo de aprendizagem contínua. No entanto, o apego ao passado centrado no ethos legal é mais forte do que acompanhar o mundo vivido da pessoa. Escutar o ser humano com seus dilemas e conflitos, acompanhando-o em suas escolhas, é dever cristão. Se o passado ensinou pecados objetivos na escuta do confessionário, o passado formou, na expressão de Bernardino Leers, o especialista em pecados. Este vive até hoje em nosso meio, daí uma dificuldade de encontrar um teólogo moral que acompanhe o tempo vivido.

É a espera institucionalizada do saber moral que impera sobre a consciência do moralista. Como se os valores estivessem atrelados ao ethos legal. A exemplo, Bernardino surpreende com sua fidelidade à moral da pessoa e a sua crítica ao modo de se fazer teologia moral. Para ele ocorre um elitismo na teologia moral.

É um termo que pode ser usado em várias direções. Um primeiro sentido aparece na forma da tentação, de preguiça e comodismo que ameaça o moralista. Se surge um novo problema social ou novidade científica, ou o profissional não quer perder o emprego, é só esperar um tempinho e já sai publicada uma resposta eclesiástica do Vaticano ou da CNBB. A moral parece descer de cima para baixo e desconhecer o princípio da subsidiaridade. Um outro sentido, apresenta-se nos muitos discursos sobre assuntos e pessoas, sobre sexualidade ou política, sobre pobres, mulheres, homossexuais, mas não há sinal de que a reflexão saia destes agentes morais ou de pessoas que estão envolvidas neste ou naquele desafio moral ${ }^{28}$.

O modo de se fazer teologia moral católica a partir do povo é inspirado na proposta do Vaticano II, que abre possibilidades de se perceber a força do leigo. No entanto, como vimos, é a moral dos manuais que formou uma boa parcela da vida eclesiástica daqueles que assumiram a hierarquia católica. Espera-se um ethos normativo. A resistência ao modo de se ensinar o que é certo e o que é errado abre possibilidades para um personalismo abstrato de João Paulo II. Frei Bernardino caminha numa direção de pensar a pessoa em sua concretude numa nova perspectiva do ser moral. Assim afirma,

Encarar a moral dessa maneira propicia uma outra base para reflexão. Porque eu, agora, sou obrigado não a estudar a história da teologia normativa,

${ }^{28}$ B. LEERS, Em Plena Liberdade, Belo Horizonte: Lutador, 2010a, p. 20. 
mas estou obrigado a escutar calmamente o que esse homem, essa mulher têm a falar. Tenho que interrogar a motivação. Tenho de estudar, então, muito mais as pessoas na sua concretude, para descobrir com ela, não por cima dela, sua problemática. Com todo o problema da tolerância, da paciência. Ninguém muda de uma vez e totalmente ${ }^{29}$.

Com essa perspectiva de pessoa em sua concretude, o itinerário da sabedoria de Bernardino se faz. Levando em conta seu aprendizado de uma escuta cuidadosa do outro, maltratado pela vida, e com um acolhimento religioso na maioria das vezes carregado de conceitos e juízos já formados. Tem em vista que a morada do sujeito ético está circunscrita à sua condição de ser pessoa. Frei Bernardino Leers, como um sacerdote que abre caminhos para que a pessoa seja, aprende com ela a utilizar o que há de mais belo na ação ética, a capacidade de indignação e o insurgir-se contra normas estabelecidas, trazendo o outro em cena numa relação possível de convivência mútua.

Dessa forma, Frei Bernardino, na sua condição de presbítero, é o portador de uma linguagem oficial e cristã que, no sentido tradicional, manda o que deve ser feito, atitude que o povo aprendeu em sua obediência religiosa. Em sua atitude moral frente ao outro, Frei Bernardino aprende que a ação do povo caminha numa outra direção. É uma ação de quem vive independente da lei e do que se espera. É uma ação de quem aprende a escutar e a escolher o que é possível fazer. Assim um modo particular de viver uma vida que é mais dura para alguns, um jeito de viver, um jeito brasileiro de ser. Aponta um caminho na práxis da moral teológica, na qual a direção é o outro, numa escuta respeitosa e cuidadosa do ser humano.

Esse aprender e fazer com o povo funda uma moradia. A morada do povo independente da religião. Ela é construída numa ação solidária da boa vivência e convivência na solução de conflitos e de dilemas. É a categoria povo criticada na academia, mas vivida em sua prática, o que se pode nomear como ethos popular em seus costumes e crenças.

Compreender a vivência do ethos popular é identificar os termos ética e moral sem diferenciá-los. A ética, como atitude reflexiva sobre os valores morais, abre-se no que se refere à práxis do povo, a uma identificação com a moral. Dessa forma, os termos ética e moral indicam os costumes, o dever ser, a maneira de agir no mundo de acordo com sua consciência e com o que se vive:

A moral da Igreja católica ocidental, com sua tirania do medo, mostrou sua ineficácia para os novos tempos. Aliás, segundo Frei Bernardino, "na sabedoria popular, o medo sempre foi considerado um mau conselheiro" ${ }^{30}$.

${ }^{29}$ L .L. PEREIRA; S. F. P. TOSTA (Org.), Frei Bernardino - Um jeito de Viver: Sociedade religião e moral. Petrópolis: Vozes, 2000, p. 30.

${ }^{30}$ B. LEERS, "Moral Tradicional", Revista logos ano II, n. 4, outubro 1975, p. 9. 
Quando as pessoas vivem a vida de acordo com suas consciências, formadas ao longo do tempo, aprendem que um sistema de normas é fundamental para a vida em sociedade. Aprendemos ser preciso estar aberto à mudança para o novo que surge, que se tornará velho, e será transgredido pelo outro novo, assim por diante.

A queixa em relação à crise do "mores-costumes" não é nova. Dentro da religião cristã sempre que um sistema de costumes se modifica, os especialistas em pecados, de plantão anunciam o fim do mundo. A crise é fundamental na dinâmica do ethos ao fazer com que os indivíduos retornem às origens do problema que se apresenta. Para Frei Bernardino ${ }^{31}$, a crise moral se torna também mais compreensível, mais desafiante se a insegurança das atitudes e normas da vida é colocada no seu contexto. Contexto real duma humanidade que passa, em ritmo acelerado, por transformações profundas em suas relações mútuas e em relação com mundo cósmico em que vive.

É o comportamento moral que vai delineando a face do ethos nessa dinâmica quando compreendemos a pessoa em seus dilemas e conflitos e ao mesmo tempo percebemos a tentativa inócua de conservação da moral constituída. É o campo da consciência moral que muda o foco que antes estava vinculado a princípios considerados eternos e eram aplicados casuisticamente, de tal maneira, a tirar conclusões lógicas de como devem ser as coisas. Um vício dos manuais de Teologia.

É curiosa a maneira pela qual a moral religiosa responde a questões ligadas à vida em geral, como se negasse a possibilidade da diferença e do novo. Na área da sexualidade é evidente tal reação. Desde os estudos de Freud é impossível pensar na pessoa sem levar em conta sua sexualidade. Nesse campo, ao que tudo indica, alguns moralistas católicos tem dificuldades em discutir essa temática. Frei Bernardino, como um homem de seu tempo, passou a discutir a sexualidade centrando-se na idéia do ser pessoa. Foi assim com questões ligadas à natalidade, no que se refere ao uso da pílula, ao aborto, e, especialmente, à pessoa homossexual.

No que se refere ao controle de natalidade, enquanto os moralistas estavam à procura de pecados, ele aponta para uma reflexão em torno da vida amorosa e de que maneira será possível viver de modo cristão com essa mudança de costumes. Na metade dos anos 60, questões dos métodos ligados ao controle de natalidade estavam demarcando a moral sexual. Bernardino aponta para a responsabilidade dos casais cristãos e faz a crítica aos moralistas:

O pastor das almas não pode duvidar da seriedade responsável de muitos casais católicos de elevada vida moral que, ou aplicam estes meios com a

${ }^{31}$ Cf. Ibid., p. 12. 
consciência tranquila, ou não os querem aceitar, não porque a consciência pessoal os acusa, mas exclusivamente porque a Igreja, o padre, não deixam ${ }^{32}$.

Como a formação da lei moral vem também da instituição religiosa, é preciso ampliar a compreensão dos novos valores dentro da Igreja, para saber orientar os fiéis que são pessoas e que de uma certa forma legitimam o poder da instituição. Quanto a isso, Frei Bernardino volta-se para a questão da pílula, mostrando a necessidade dos moralistas compreenderem melhor qual é a função da teologia moral. "A serviço da Igreja e dos homens, a teologia moral há de procurar novas perspectivas na discutida questão da pílula, que talvez possam esclarecer a verdade e orientar a atitude moral a tomar" 33 .

A reflexão de Frei Bernardino no que se refere ao uso da pílula foi a de remontar à questão dos fundamentos do matrimônio cristão de modo a mostrar que uma revisão dos princípios utilizados pela moral era necessária. Ao transformar uma questão de ordem prática em teórica, o autor toca na importância de se pensar o matrimônio e sua significação. $O$ fato sai da questão prática em direção a vida da pessoa em sua vivência do espaço constituído de convivência. É “o conjunto de vida-casa” numa experiência que se abre em várias dimensões apontadas por Bernardino: abordagem religiosa, interpessoal, sexual, bissexual, procriativa e social. Essas dimensões estão no cerne do matrimônio, o que abre possibilidades para se compreender a pessoa em suas relações. Nesse voltar para pessoa, Frei Bernardino coloca a questão da pílula como um método que "se elucida no conjunto da comunhão encarnada dos esposos [...] Não importa se é o homem ou a mulher quem toma a pílula. Limitação de filhos significa, como atividade humana, auto-limitação do casal em seu amor matrimoni$\mathrm{al}^{\prime \prime 34}$.

É essa ousadia de tocar no que era considerado intocável, que Frei Bernardino avança na reflexão moral. Mostra que a pílula não seria uma infração à natureza humana ou contra a ordem divina quando afirma:

A obediência fundamental do homem a Deus nunca significou um respeito passivo que apenas segue as linhas que a natureza do mundo e do homem parece indicar. O mais simples instrumento de trabalho e o mais primitivo método de cultivar a terra já provam o contrário. A natureza do mundo e do homem não é um museu em que a liberdade humana apenas pode orar e admirar, de braços cruzados sem tocar em nada. A natureza que o homem encontra e decifra é o ponto de partida da cultura humanizadora ${ }^{35}$.

${ }^{32}$ B. LEERS, Em Plena Liberdade, Belo Horizonte: Lutador, 2010a, p. 121.

${ }^{33}$ Ibid., p. 123.

${ }^{34}$ B. LEERS, Em Plena Liberdade, Belo Horizonte: Lutador, 2010a, p. 142.

${ }^{35}$ Ibid., p. 143. 
É essa cultura humanizadora que faz Frei Bernardino, no campo da moral, buscar no prático o fundamento teórico para mostrar que a teologia moral tradicional carece de se atualizar. Só assim pode-se compreender a dignidade do ser pessoa, antes de se apegar ao formalismo da lei e a pressupostos que estão longe da proposta original cristã.

Com essa perspectiva atenta aos costumes é possível refletir sobre a vida que tem seu fim no aborto ou na eutanásia, levando em conta a condição de tempo e de espaço vividos e a condição concreta das pessoas envolvidas no drama humano. Concomitante a essa situação, Frei Bernardino aponta para a inabilidade dos moralistas que se esquivam discutir os novos valores.

Ao formular a problemática do aborto, Frei Bernardino aponta para a questão do gênero feminino uma vez que "os dramas de aborto talvez digam pouco aos homens, mesmo se são co-responsáveis pela origem do problema, mas são sentidos tanto mais profundamente pelas mulheres que são, afinal de contas, as principais agentes e vítimas destas histórias"36.

Se o aborto é considerado um pecado mortal, Frei Bernardino o redimensiona na perspectiva da pessoa. Segundo ele,

Nos casos de aborto, sempre duas vidas humanas estão diretamente envolvidas: a vida de quem é abortado e a vida de quem aborta. Pela focalização epocal na vida do primeiro, não se corre o risco de deixar na sombra a segunda, que leva o estigma de crime hediondo e pecado mortal e excomunhão reservados? ${ }^{37}$.

É assim que, problemas de uma ética aplicada estão presentes em seu pensamento ao estar atento às mudanças do tempo vivido. Os temas polêmicos surgem e ressurgem e Frei Bernardino lida com eles sendo fiel a sua proposta em centrar sua reflexão na pessoa.

No que se refere à homossexualidade, a pessoa deve ser compreendida no território da sexualidade e não do preconceito. Para ele, homossexualidade somente ganha face humana se é colocada pela pessoa humana concreta em sua história própria. $\mathrm{O}$ ser humano não é uma essência parada no tempo e isolada no espaço ${ }^{38}$.

Ao compreender a situação do homossexual em relação ao heterossexual, Frei Bernardino volta-se para a pessoa. E de forma crítica aponta que a identidade sexual da pessoa homossexual felizmente não se evidencia "somente

\footnotetext{
${ }^{36}$ Ibid., pp. 148-149.

${ }^{37}$ Ibid., p. 154.

${ }^{38}$ B. LEERS; J. TRANSFERETTI, Homossexuais e Ética Cristã Campinas: Atomo, 2002, p. 57.
} 
quando um grande talento artístico ou intelectual é capaz de desviar bastante a atenção curiosa e maligna pelo fato de ser o portador um homossexual"39. É como se sua identidade sexual não existisse. Como se o mundo fosse do e para os heterossexuais. Esse é um campo fértil para a questão moral e ética das pessoas principalmente aquelas que se consideram cristãs. Ocorrem discriminações sociais embutidas em códigos de conduta. Para ele,

Na história de um homossexual, a religião pode desempenhar o papel de apoio e animação ou provocar afastamento e ódio. Os maus tratos, o desespero, a zombaria, sofridos nas mãos de cristãos, podem criar tanta desilusão e fortalecer tanto senso de isolamento e exílio, que a pessoa se sente rejeitada em sua igreja e fixa em seu coração a imagem de um deus cruel que castiga e abandona no deserto social a ovelha perdida ${ }^{40}$.

Ao chamar a atenção para a questão discriminatória em relação aos homossexuais, Frei Bernardino aponta para a ausência de formação e informação do clero em relação às mudanças sociais e ao mesmo tempo para o despreparo em lidar com temas da sexualidade. É preciso ficar atento ao mundo vivido e a partir daí ter uma escuta verdadeira de sofrimentos em relação a conflitos e dilemas. Uma vez que,

Se a árvore do bem e do mal está implantada simbolicamente nas consciências morais das pessoas e a fé faz também dos homossexuais cristãos templos do Espírito santo, não há sentido de decidir normas sobre a conduta deles, sem eles participarem com voz ativa e finalmente liberada do processo decisório. Adultos e maduros, são eles os responsáveis históricos diante de Deus e diante da comunidade que participam ${ }^{41}$.

É o campo da autonomia e da liberdade sendo construído em conjunto. Essas perspectivas de educação para o ser pessoa livre e responsável coloca Frei Bernardino em destaque na vida eclesiástica, especialmente no meio dos moralistas católicos. É uma nova forma de compreender os fiéis nesse conflito de desejos e de dilemas humanos, dentro da verticalidade religiosa. Essa preocupação com o mundo vivido da pessoa e essa escuta sábia do povo levaram-no a propor uma ética do confessor centrado na pessoa.

\section{3 - A morada do Confessor}

Errata: onde o Antigo Testamento diz o que diz, deve dizer aquilo que provavelmente seu principal protagonista me confessou: Pena que Adão fosse tão burro. Pena que Eva fosse tão surda. E pena que eu não soube me fazer entender. Adão e Eva eram os primeiros seres humanos que nasciam

\footnotetext{
${ }^{39}$ Ibid., p. 170.

${ }^{40}$ Ibid., p. 170.

${ }^{41}$ Ibid., p. 168.
} 
da minha mão, e reconheço que tinham certos defeitos de estrutura, construção e acabamento. Eles não estavam preparados para escutar, nem para pensar... [...]. Então, vieram os equívocos. Eles entenderam queda onde falei vôo. Acharam que um pecado merece castigo se for original. Eu disse que quem desama peca: entenderam que quem ama peca. Onde anunciei pradaria em festa, entenderam vale de lágrimas. Eu disse que a dor era o sal que dava gosto à aventura humana: entenderam que eu os estava condenando, ao outorgar-lhes a glória de serem mortais e loucos. Entenderam tudo ao contrário. E acreditaram $[\ldots]^{42}$.

A situação do confessor no mundo contemporâneo provoca reflexões que problematizam duas perspectivas: a de uma escuta cuidadosa no que se refere a questões polêmicas como vida conjugal, eutanásia, distanásia, violência, sexualidade, aborto, homossexualidade que exigem do teólogo moralista posicionamentos em relação a pessoa e não a ethos legal/eclesiástico; e a de se fazer de uma ética aplicada que tematize conflitos, dilemas e deveres circunscritos ao campo da prática pastoral e confessional. Essas perspectivas, no pensamento de Frei Bernardino, ficam claras quando o autor reflete essas questões polêmicas que, segundo ele, deveriam estar no dia a dia do teólogo moralista. Elas o colocam numa situação paradoxal. De um lado, é servo de uma Igreja que se posiciona à contramão dos novos tempos. Por outro, deve ser sensível às novas demandas da pessoa em seu processo de libertação.

É nessa situação paradoxal que o campo da ética aplicada torna-se fundamental para problematizar questões ligadas à vida. De que maneira a ética aplicada, na ação do confessor, levaria a uma idéia de bem e de responsabilidade da pessoa em relação à vida? Essa indagação é respondida quando se investiga a intenção de Frei Bernardino em relação ao ideal de se viver bem e em harmonia a partir dessa luta entre contrários.

Ao refletir sobre a moral brasileira, o autor traça a origem dessa moralidade em Portugal e no processo de romanização da religião católica, chama a atenção para a importância da Igreja no processo de formação cultural que o próprio Honnaert já tinha sistematizado. No entanto, a compreensão de um ethos popular, nessa interação com o código moral, se dá na ação e nessa escuta cuidadosa em relação à pessoa na sua singularidade. Estar em consonância com os princípios da Igreja e a prática do povo é um exercício de humildade e sabedoria, tendo em vista que a Igreja Católica no Brasil sempre esteve à volta com questões instigantes. Bernardino chama a atenção para valores tradicionais da família, Igreja e Estado. Assim, a

monogamia, indissolubilidade, legitimidade da prole eram normas da moral católica e das leis civis; de uma ou de outra maneira, tanto as sanções do

${ }^{42}$ GALLEANO, Eduardo. O Livro dos Abraços. Porto Alegre, L\&PM, 1991, p. 89. 
pecado, quanto as determinações do direito penal encobriram o homossexualismo, a prostituição, o aborto voluntário, o adultério ${ }^{43}$.

Esse jeito de se esquivar de temas cruciais colocou os teólogos moralistas em situação de conservadorismo em relação à vida do povo. Daí que reflexões em torno da sexualidade, casamento e família exigem do confessor uma escuta apurada e cuidadosa. Várias questões ligadas à vida do povo levaram Frei Bernardino a problematizar, de forma lapidar, o que é próprio da pessoa e a ter uma postura crítica em relação ao ethos eclesiástico.

Seu pensamento aborda desde a família nuclear, fechada em torno de pai mãe e filhos, até ao modo contemporâneo de se pensar essa instituição. Perpassa questões ligadas à sexualidade e faz sua crítica de forma irônica aos confessores que invadem a vida das pessoas sem conhecer o mundo vivido por elas. Assim, para ele o confessor deve estar atento a toda manifestação da vida do outro. Nessa ética, o confessor tem o compromisso primeiro com a pessoa em seus dilemas e conflitos. A ética do confessor proposta por Bernardino situa-se nesse campo da aplicação. É preciso tornar-se um pedagogo que aprende a conduzir, no campo da fé, os fiéis independente da cor da pele, dos olhos, das escolhas sexuais.

A construção e reconstrução do ethos religioso tem, no confessor, um lugar para a responsabilidade com a pessoa. Essa preocupação de Bernardino conduz sua forma de agir moralmente e, ao mesmo tempo, sua escuta cuidadosa do outro.

A experiência de uma vida voltada a escutar dilemas e conflitos levou-o a um refinamento no modo de pensar e de agir de forma autônoma, o ideal necessário para qualquer pessoa. Para ele, é inconcebível a prática de alguns teólogos moralistas ao estabelecer o que deve ser, a partir do ethos legal eclesiástico. Ou melhor, é o mundo do ethos legal num retorno a uma nova forma de obedecer a manuais de conduta. Para Bernardino, tal atitude conduz a um elitismo que é o da ausência de liberdade. Assim formula a questão que de uma certa forma incomoda aos moralistas de plantão: Quais são as pessoas concretas de carne e osso que desfilam pelo discurso dos teólogos morais e autoridades, quando formulam normas? E faz o seguinte comentário: "As vezes, tenho a impressão de que ainda é Adão, quando andava ainda puro e livre pelo Paraíso, o homem perfeito completo que ainda não abusara do investimento de alto risco que Deus lhe fez, chamado liberdade" ${ }^{44}$.

${ }^{43}$ B. LEERS, "Filosofia, moral, ética família e sociedade no Brasil (1964-1984)", in I. RIBEIRO (Org.), Sociedade Brasileira Contemporânea-Família e Valores, São Paulo: Loyola, 1987, p. 132.

${ }^{44}$ B. LEERS, Em Plena Liberdade, Belo Horizonte: Lutador, 2010a, p. 20. 
É nessa possibilidade de ser livre e autônomo que Bernardino aponta para a teologia moral como um lugar em construção assim como a morada do ser humano que não está pronta acabada, perfeita. Uma vez que, "A teologia moral não é para os perfeitos, mas para pessoas em caminho, em construção ainda não prontas" ${ }^{45}$.

Em seu livro, O Ministério da Reconciliação - uma ética profissional para confessores, de 1988, Frei Bernardino dá o tom e a dobra para essa possibilidade de reconciliação, pela qual o ministro é responsável pela mediação necessária de libertação. O confessor não é um especialista em pecados, mas uma pessoa aberta à possibilidade permanente de conduzir ao caminho do que é o bem.

Atento ao tempo e às mudanças no campo da moral, discute de forma lapidar o que é essa escuta cuidadosa ao acolher o outro, independente de suas escolhas sexuais, políticas e/ou pessoais. Para ele, a pastoral centrada na pessoa humaniza o teólogo moral, leva-o a compreender processos sociais e a entender melhor dilemas e conflitos humanos. É o caminho do meio, da virtude de saber ouvir. Ter a paciência de esperar, a tolerância de suportar e escutar o que não se deseja. Nesse caminho, aponta para questões delicadas que o ethos legal/moral, numa perspectiva eclesiástica tradicional, tem dificuldade de compreender e conduzir: são as situações dos recasados e dos homossexuais. Questões que no campo da ética aplicada não são moralizadas. Frei Bernardino ${ }^{46}$ as coloca no território de conflitos e dilemas para o confessor, levando-o a entender a pessoa concreta, no mundo concreto. De tal forma, que a condenação posta pelo ethos legal/ moral numa perspectiva eclesiástica tende a mudar uma vez que: Dentro do ambiente do confessionário, o ministro não está em primeiro lugar no nível das normas, mas no nível das decisões históricas de consciência, tomadas por outras pessoas concretas, em situações próprias.

Essa perspectiva de Frei Bernardino, se voltar para o mundo da pessoa e a partir daí acompanhar seus dilemas e desafios, clama aos teólogos moralistas pela sua obrigação de ser pedagogo, se quiser, catequista. Em seus escritos de teologia moral, as situações familiares e sexuais são abordadas de forma ética ao pensar no outro em suas escolhas e ao mesmo tempo, na postura do confessor. Conversar com o outro, acolhê-lo sem excluir, sem tirar dele a possibilidade de se reconciliar, fazer com que o individuo se sinta parte da vida, é para Frei Bernardino uma missão. Assim, ele se posiciona frente a essas situações que chamam à reflexão:

Um homem mutilado fracassado e mutilado pela experiência negativa de seu primeiro casamento não dispõe das mesmas condições de se recuperar,

45 Ibid., p. 21.

${ }^{46}$ B. LEERS, O Ministério da Reconciliação: Uma Ética Profissional para Confessores, Petrópolis-RJ: Vozes, 1988, p. 158. 
emendar-se, consertar a situação, de que dispõe aquele que está acertando seu casamento. A questão não é a aprovação da solução limitada de emergência que o penitente deu. Compreendendo prudentemente a necessidade relativa em que ele se encontra, o ministro não o jogará mais ainda no abismo, lembrando-lhe leis que ele não consegue alcançar mais; muito menos há de condená-lo ou tratá-lo com dureza farisaica... O mesmo se verifica com os homossexuais [...] Sem entrar no mérito das questões de como as pessoas evoluem para tal forma de orientação sexual, no confessionário apresentam-se pessoas com esta orientação que as torna incapazes de se casarem com pessoas do mesmo sexo. Qualquer sugestão do confessor em direção ao matrimônio seria condenar a uma vida de inferno ${ }^{47}$.

É essa ética profissional que Frei Bernardino demonstra em seus escritos e em sua vida, ao afirmar que o ministro encontra-se numa situação eclesiástica paradoxal. De um lado a lei eclesiástica determinando o que deve ser e do outro aquilo que é. É mais fácil seguir a lei e não ver o que diz a realidade. No entanto, a pergunta que surge em Bernardino e no mundo do vivido é a seguinte: Agir dessa forma é justo? De forma lapidar, Frei Bernardino ensina ao confessor ou aos aspirantes da teologia moral:

A Igreja impõe regras gerais de conduta pastoral. Estas podem tornar a posição do ministro dolorosa, como pressionado entre duas forças. De um lado, o peso dos decretos eclesiásticos, do outro o penitente. Mais fácil é obedecer cegamente aos primeiros; às vezes, é mais justo e bem pensado dar preferência ao penitente e ajudá-lo a viver como cristão, enquanto praticamente pode. O dilema que sempre volta entre a lei institucional e o bem estar das pessoas merece ser resolvido prudentemente em favor das pesso$\mathrm{as}^{48}$.

Independente da moral do confessor, o que está em jogo é a pessoa em sua dignidade. Discussões essas que Bernardino apresenta, aos poucos aos moralistas. Para ele, o teólogo moralista precisa acompanhar a memória e a história da pessoa, escutá-la de seu lugar puramente humano, uma vez que:

Passou a época em que o teólogo moralista ensinava "ex cathedra", vinte centímetros acima de seus ouvintes. Na mão segurava o manual da teologia moral para uso de confessores de um ou outro autor em latim. Em latim ou, se tinha coragem em língua vernácula, explicava a doutrina fixa da moral oficial, controlada pelo Santo Ofício. Para variar, seu monólogo era intercalado com um ou outro caso ou piada ou resposta a uma pergunta de um ouvinte atencioso. Passou a época em que nosso povo era bom, mas ignorante, e o clero dominava o espetáculo. A separação entre o padre pregador e o mestre e o público em silêncio era clara. Pecados e confissões eram prato

${ }^{47}$ B. LEERS, O Ministério da Reconciliação: Uma Ética Profissional para Confessores, Petrópolis-RJ: Vozes, 1988, p. 159.

${ }^{48}$ Ibid., p. 161. 
comum, com alimento aberto na frente e a morte uma luta brava entre anjos bonitos e demônios-monstros ${ }^{49}$.

Passou o tempo e a formação do moralista mudou muito pouco na percepção de Frei Bernardino, pois há poucos teólogos moralistas atentos aos dilemas e desafios da pessoa. E de forma irônica conclui que no canteiro de obras humanas está afixado "vagas para teólogos moralistas que têm coragem", e nós completamos, e que sejam justos.

\section{Considerações finais}

O pensamento em torno das questões morais propostas por Bernardino vai ao encontro da chamada ética aplicada. Essa aproximação faz de Frei Bernardino um autor indispensável no campo da filosofia e no da teologia, especialmente no que se refere às questões morais. Ter contato com algumas obras permitiram-nos compreender a complexa teia de crise de valores e de formação para a estruturação do pensamento moral. $\mathrm{O}$ autor oferece pistas para uma moral teológica aplicada, uma vez que a morada da moral está circunscrita na pessoa em seus conflitos, dilemas, direitos e deveres. O lugar da moral é na escuta cuidadosa do outro, aprendido no convívio com a sabedoria popular.

O pensamento de Frei Bernardino Leers aponta para a morada da moral a partir de uma perspectiva cuidadosa, ao aliar, a formação valorativa religiosa aos novos tempos. Hoje existem temáticas que exigem do sujeito reflexões aprofundadas para tomada de decisões que envolvem a pessoa em sua responsabilidade diante da vida.

Temas polêmicos exigem do moralista a autonomia e a sabedoria de se relacionar com o outro. A vida ética só tem sentido na relação com o outro em seu mundo vivido. Por um lado, a vida religiosa dos teólogos apegados à tradição é renovada pela normatividade de um ethos puramente legal. Por outro, dentro da própria religião católica em regime de exceção, a vida é abrilhantada pela insurgência transgressora na arte de viver bem de acordo com a sua consciência. Frei Bernardino Leers tem mostrado que a dignidade ética pode também ser cristã e católica.

É importante ressaltar que a escolha e a fundação do ethos popular propicia uma reflexão que, às vezes, em seus comentadores, situam Bernardino como um homem do povo na compreensão do Catolicismo Popular. Tal perspectiva é incorreta no momento em que se debruça sobre sua obra. A

49 B. LEERS, "Formação Teológica e Formação Presbiteral", Horizonte Teológico, Ano 8, n. 16,2009 , p. 13-14. 
vivência de Bernardino no mundo rural proporciona uma compreensão do mundo vivido, numa construção e reconstrução do ethos que tem no indivíduo a sua universalidade. O ser humano é um só, faz parte da sua condição os conflitos, os direitos, os deveres e os dilemas. Independente de estar na vivência do mundo rural, o que afirmou várias vezes em seu aprendizado, sua reflexão aponta para além desse vivido. Uma vez que sua preocupação é com a pessoa, com o outro, independente de sua condição social, cor da pele, língua, escolhas sexuais etc. Sua reflexão a partir do povo apenas mostra e reforça sua opção religiosa e sua escolha a quem servir.

Em sua ética aplicada ao confessor, pensar na pessoa é aprender com ela. Escutar o que não se deseja. Aprender a fazer mediações daquilo que se é e se deseja ser; é cultivar a esperança de ser a cada dia mais justo e, em sua unidade de referência, aprender a ser mais cristão, estando no magistério da fé.

É no ethos da pessoa que, antes da reflexão moral, reside a morada do ser em seu processo contínuo de construção e reconstrução da vida. Ao debruçarmos sobre o pensamento de Frei Bernardino, sendo um dos autores desse artigo seu discípulo, e o outro um leitor de suas obras, ao conhecêlo de perto podemos afirmar: uma vida moral e ética é uma extensão do que se acredita e se vive. Sua relação de tolerância que se abre ao outro é um processo longo de ensinar e aprender. Viver com dignidade e justiça é aprender a cada dia com o outro nesse tempo de chegar e partir. No caso do autor, ao chegar aos seus noventa anos, antes de partir deixou inscrito no tempo da memória, a sabedoria de olhar para trás e dar forma ao conteúdo do vivido. Assim, procede como os grandes sábios do passado que foram pessoas do seu tempo.

\section{Referências Bibliográficas:}

LEERS, B., "Moral Tradicional”, Revista logos (Divinópolis MG) ano II, n. 4, outubro 1975 .

Ensinar Teologia Moral, In: M. FABRI DOS ANJOS (Org.), Articulação da Teologia Moral na América Latina, São Paulo: Santuário, 1986.

"Filosofia, moral, ética família e sociedade no Brasil (1964-1984)", in RIBEIRO, I. (Org.), Sociedade Brasileira Contemporânea: Família e Valores, São Paulo: Loyola, 1987.

O Ministério da Reconciliação: Uma Ética Profissional para Confessores, Petrópolis: Vozes, 1988.

; TRANSFERETTI, J., Homossexuais e Ética Cristã, Campinas: Atomo, 2002.

n. 16, 2009.

"Formação Teológica e Formação Presbiteral", Horizonte Teológico, Ano 8, 
Teologia Moral, Ciências Humanas e Sabedoria Popular: Um Tripé que deu certo, Petrópolis: Vozes, 2010b.

Em Plena Liberdade, Belo Horizonte: Lutador, 2010a.

ARENDT, H., Entre o passado e o Futuro, São Paulo: Perspectiva, 2000.

BENJAMIN, W., Obras Escolhidas: Rua de Mão Única, São Paulo: Brasiliense, 1993.

LA TAILlE, Y. de, Vergonha a Ferida Moral, Petrópolis: Vozes, 2002.

LIMA VAZ, H. C., Escritos de Filosofia II, São Paulo: Loyola, 1988.

PEREIRA, L. L.; PEREIRA TOSTA, S. F. P. (Org.), Frei Bernardino - Um jeito de Viver: Sociedade religião e moral, Petrópolis: Vozes, 2000.

Amauri Carlos Ferreira é graduado em Filosofia ( PUC Minas), mestrado ( PUC São Paulo), doutorado (UMESP) em Ciências da Religião e pós-doutorado em Educação (UFMG).

Leonardo Lucas Pereira é graduado em Filosofia e Teologia, especializado em Sociologia do Desenvolvimento e Urbana (Sorbonne, França). 